\title{
Diverse Forms of V-learning Students' Acceptability During the Pandemic Covid-19
}

\author{
Ita Fatkhur Romadhoni ${ }^{1,{ }^{*}}$ Dwi Kiristiastuti ${ }^{1}$ Luthfiyah Nurlaela ${ }^{1}$ Any Sutiadiningsih ${ }^{1}$ \\ Nugrahani Astuti ${ }^{1}$ Lucia Tri Pangesthi $^{1}$ Sri Handajani ${ }^{1}$ Niken Purwidiani ${ }^{1}$ \\ Suhartiningsih ${ }^{1}$ Asrul Bahar ${ }^{1}$
}

${ }^{1}$ Faculty of Engineering, Universitas Negeri Surabaya, Surabaya
${ }^{*}$ Corresponding author. Email: itaromadhoni@unesa.ac.id

\begin{abstract}
Covid-19 pandemic encourages online learning to prevent wider spread. Various types of learning platforms were implemented, but there needs to be an evaluation of student acceptance of the platforms. This study aims to assess the impact of v-learning on student acceptance during a pandemic. The v-learning analyzed is limited to Vilearning Unesa (VU), Google Meet (GM), and Zoom. The information-gathering procedure is implemented through Google Forms and distributed through a WA link. The study is analyzed by a Likert scale for student acceptance, involving easy accessibility, peer instruction, and user experience. Multiple regressions were analyzed by following participant information. The findings indicate discrepancies in student acceptance of the v-learning being applied. VU offers the advantage of incorporating the system into academic services for students, while Zoom has easy and smooth access to the network. Increased primary education learning results are b1: 0.518; b2: 0.119. In other words, although GM lacks personalization facilities, nearly $80 \%$ of respondents can accept it. That concludes GM is superior to VU and Zoom according to user satisfaction due to the streamlined infrastructure with GM that Google offers. Future studies are expected to involve observations not only for students but also by lecturer feedback.
\end{abstract}

Keywords: Covid-19, student acceptance, V-learning, Vilearning Unesa (VU), Google Classroom (GC), Zoom

\section{INTRODUCTION}

The government has issued a school policy requiring students to study at home to prevent the Covid-19 pandemic. For students beginning in March 2020, the education system has introduced online learning approaches. Alternatively, online course platforms were selected to provide course material to the participants as a replacement for face-to-face classroom meetings. Various online learning sites are used by academics. Online learning is considered a solution to continuing teaching and learning activities during the Covid-19 pandemic.

the essence of the topics which students receive every day. In one day are provided only three types of subjects, including the exercise sheet, to be completed
Although it was agreed, this method was conflicting. Online learning systems are useful for assignments only to teachers. They consider making the material understand to students, the way it is deemed difficult online. Furthermore, each student has specific practical and environmental capacities [1]. Not all students are provided with facilities that support distance learning. The real obstacles are slow to access, inadequate devices, and expensive internet quotas. But somehow it must continue to study. Every school has its policies regarding this regulation. For example, Unesa, giving internet quota to all students every month to reimburse the cost of the internet for online tuition. Many other schools are able, to sum up,

every day by students. Thus, with various types of online media choices, questions arise about how much 
detail this media can accommodate the needs of teachers and students.

The Vilearning Unesa (VU), Zoom, and Google Meet (GM) platforms were chosen to be observed because these three media are most often used in the learning process and are familiar among academics. Moreover, VU has become the Unesa students' most well-known forum. VU has the advantage of integrating students with an integrated academic system making it easier for students to manage lectures according to the schedule each semester [2]. Just like VU, GM has become a v-learning platform, integrated with many common requirements, such as Gmail, Google Form, Drive, and GC services. The benefits of all these programs are for students and are accompanied by easy internet connectivity. Whereas Zoom became famous as the co-19 pandemic spread. The Zoom platform provides smooth and easy access so that many private and public sectors make Zoom a platform for conducting meetings and distance learning. Even so, the Zoom platform is exposed to several negative issues related to the security of its users' accounts [3]. Although the three v-learning platforms are popular with students, there are some shortcomings in the process of implementation, so more detailed research is needed.

Current research is needed to analyze the acceptance of student learning by v-learning services. It is important to do this study, to evaluate which type of platform would be effectively adopted in learning activities. The teachers and learners should correctly pick a good platform that completely supports educational outcomes to replace face-speaking in future learning processes. As noted [4] Interactive student communication provides an opportunity for critical thought and fresh experiences through learning on the online platform. Implementing $\mathrm{v}$-learning enables students to send messages to class discussions, to communicate and receive input from peers and teachers, and to promote a deeper understanding of such material [5]. It was emphasized that students had the right to be satisfied with the performance of online learning [6]. To evaluate the quality of online teaching and learning, this research is thus important to do. Furthermore, this study was conducted to measure how well the higher-order thinking skills and studentcentered activities continued to run. Then, the results of this study are expected to act as a guide for selecting a $\mathrm{v}$-learning platform as the core principle for further future research.

\section{METHOD}

\subsection{Techniques of Analysis and Data Processing}

This type of investigation is a case study. Case studies are a study of certain objects using samples and questionnaires. The information collected would be processed with a specific analysis. Therefore, the conclusions reached are limited to the object to be researched. The virtual learning platform analyzed is restricted to Zoom, Vilearning Unesa (VU), and Google Meet (GM).

The research subjects involved students of the Family and Consumer Science Department, Engineering Faculty, Universitas Negeri Surabaya. Data collection is undertaken following courses in Indonesian food processing and food technology. The period of study from February to May 2020. Techniques for collecting information are done using Google Forms and distributed by using Whatsapp links. There was 173 respondent of the study. In addition to the literary study, researchers use it to find further supporting needed data, including recent articles as well as other ideas.

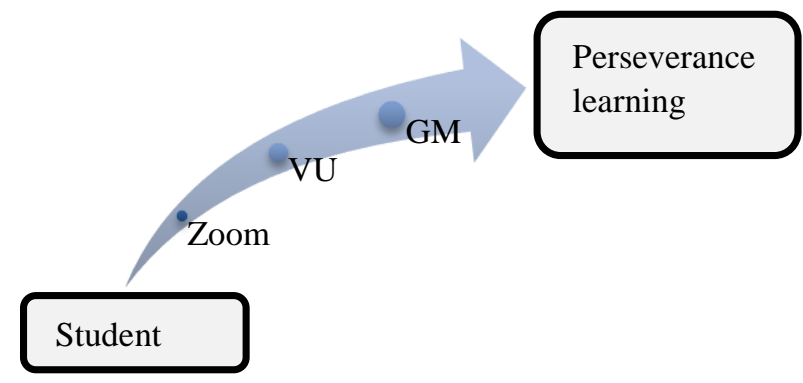

Figure 1. Testing domain setting

\subsection{Measurement and Analysis}

Research variable measurement focuses on the Vlearning platform, which includes Vilearning Unesa (VU), Zoom, and Google Meet (GM). The student acceptance variable is measured by 43 items. These criteria were tested at the start of the project of the courses have used survey methods, while the abnormalities could be corrected. Thus, before the capture study is performed out, four primary criteria have been identified that will be used as a reference for the acceptance of the V-learning platform. Measurements for student acceptance of the V-learning Platform were adapted from research [7] that included ease-to-use, personalization, and interaction student capabilities. Each measurement indicator is composed of various items. While the Likert scale is used to measure each item by using 5 scale levels. Multiple linear regression analysis by using SPSS 26 for windows was conducted for this study investigation. 


\section{RESULT AND DISCUSSION}

\subsection{Result}

The results of the platform acceptance analysis on the 'interaction' item showed a significant difference. However, surprising information was obtained that the percentage of ease of interaction using VU was almost the same as using other platforms. The most superior GM platform to provide user-friendly interaction, which is as much as $43 \%$. A comparison of the three platform types can be seen in Fgure 2 below.

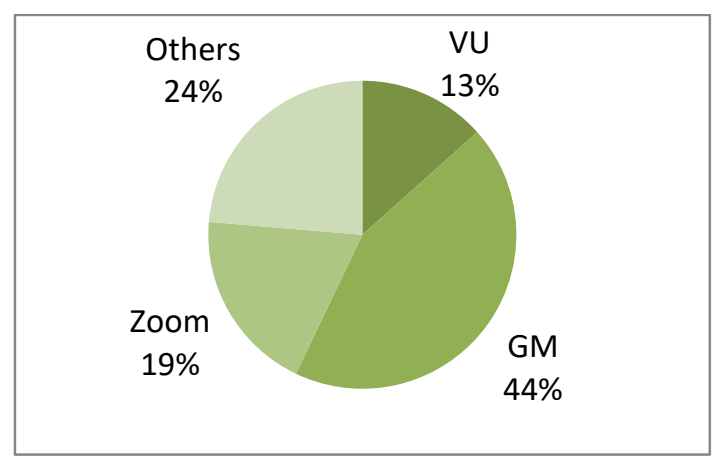

Figure 2. Interaction item Level of The Platform Acceptance

The next analysis is student acceptance for 'personalized' items. The top GM platform to make learners manage their college assignments. This can't be denied because, according to its purpose, GM is indeed designed to facilitate students in the management of classes with support for Gmail, drive, google form, and reliable server support. Whereas VU is a V-learning platform that users find difficult to customize. This result is probably inversely proportional to the main function of the VU itself. VU should be a learning platform that's easy to customize. It is because VU is designed to integrate Unesa students ' academic services, including courses in the VU.

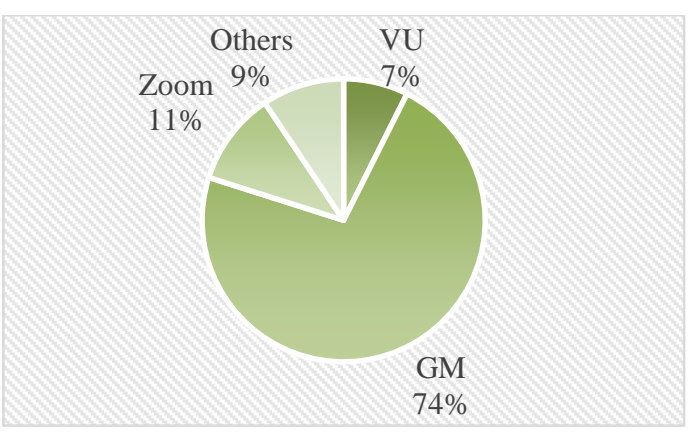

Figure 3. 'Personalised' item Level of The Platform Acceptance

Finally, student acceptance of the 'easy-to-use' item demonstrated that the GM platform was $72.8 \%$ the easiest to use. GM helps students focus on teaching smoothly everywhere, compared with VU and Zoom, through the best Server support. Particularly unique, practical, and easy processing layout for effective performance, user-friendly, supported by all involved. As well as the visual characteristics of GM are limited. Google Meet is needed to retain the quality of the platform with so many popular competitors like Zoom so that users want to use it more in comparison with Zoom or VU. Further analysis of the correlation between visualization and acceptance to students on the platform is necessary to analyze. A comparison

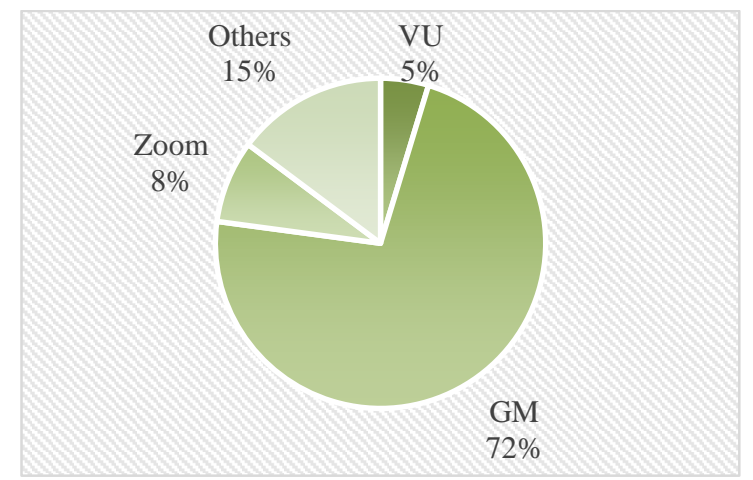

Figure 4. 'Easy-to-use' item Level of The Platform Acceptance

Regression analysis reveals that the willingness of students to communicate and personalize on both VU and GM platforms is significantly related to ease of network access, but does not significantly contribute to the Zoom Platform. That ease of network access contributes to student acceptance of VU and GM platforms $(\mathrm{r}=0.52, \mathrm{p}<0.01)$ and internet networks $(\mathrm{r}=0.32, \mathrm{p}<0.01)$. So, it can be concluded that when the v-learning platform is implemented, each network access item is related. Regression coefficient $\mathrm{b} 1=$ 0.518 means the variable level of the GM internet network increases by 0.518 compared to other variables (VU and Zoom) and correlates with the acceptance of the students. While the regression coefficient b2 $=$ 0.119 interprets that interaction between students increases on each platform. The ease of customization of each platform has a significant impact on increasing student acceptance as demonstrated by a value of 0.119 . Whereas the results of the analysis show a coefficient of $\mathrm{r} 2$ of 0.808 . Interpreted that the prevalence of the influence of network access variables, customization and fluency crossed paths with student acceptance of the platform, while $19.2 \%$ were influenced by other variables.

Hypothesis test results there is a positive influence of v-learning on student acceptance based on the component items tested. If the ease of accessing the Web on the platform is improved, the interaction between students and lecturers is getting better, on the contrary, if the web access network is slow then student acceptance of the platform decreases. Student-VU, Zoom and GM platform interactions have a major impact on student acceptance to be used. The personalization variable has a positive effect on student 
satisfaction in accessing the GM platform. The influence on the scale of the impacts of the variable interaction, the personalization, and insight into student satisfaction on the platform used as illustrated in the intensity of the coefficient of determination (R2) of 0.808 .

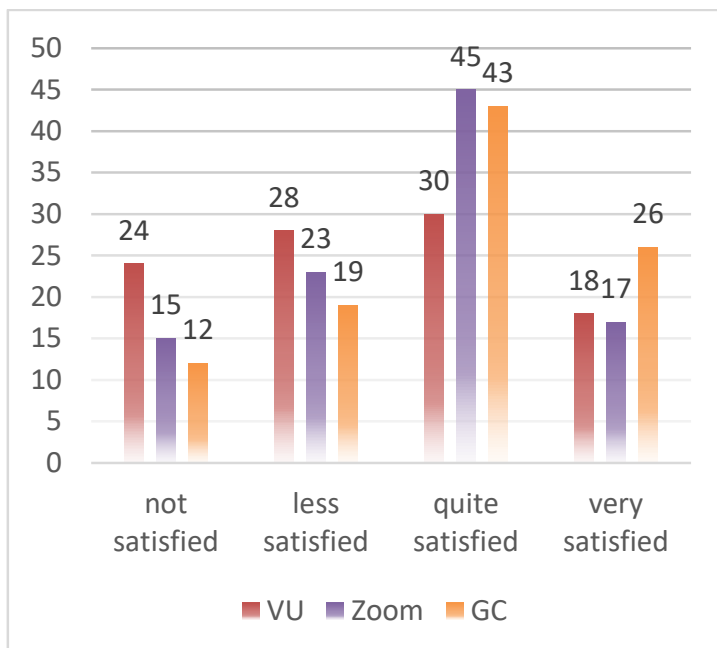

Figure 5. Level of student satisfaction with the platform

\subsection{Discussion}

The following research [8] states the ease of providing feedback in an online environment is triggered by the interaction between students that takes place comprehensively and is supported by the ease of accessing the Web platform. This opinion is also supported by [9] which states, by providing broadened pupil sharing chance their thoughts and the instructor can improve students' ability to make decisions. Consistent with the available proof of investigation, these results confirm that connection among classmates can increase the acceptance of the platform. This result is important as [10] in his project stating the lack of awareness in the classroom face to face does not necessarily occur in online classes on condition that the online class can support the needs of students during lectures. The findings of this study prove the close relationship between students increases interaction in the online environment. However, there is no significant relationship between reflective thinking ability on the type of platform applied. Of the three platforms that have been observed, it does not have an impact on increasing reflective thinking ability. So it requires more detailed research on analytics platforms to fulfill important social networking functions and create effective outcomes in communities.

Last project reported reciprocity and quality as a prerequisite for the formation of effective online learning [11]. This study, supported by claims [12] and correlated with Dawson [13], which supports the interconnection between students influencing the contribution to the lectures that he follows. An unexpected finding in this research is the insignificant user interface-interaction correlation. These results differ from the widespread acceptance view that online learning allows students to have flexible access to topics and make adjustments to their class focuses on student creativity. However, the authors argue that student habits in choosing a v-learning platform are influential so that it is in line with the research being conducted. Likewise, in this project, no significant connections were found between ease of network access and personalization on the three platforms implemented. Possible reasons are that students only focus on the material provided by the teacher so that personalized platforms are not needed. The reason for this was due to the lack of a teacher's role in providing online classroom guidance, evidenced by not being found significantly among the three platforms observed. Finally, the results support the findings by [14] which suggests that the use of various e-learning platforms makes students unfocused on personalization that is considered not important. However, the undeniable reality is, by applying one of the v-learning platforms to students can maximize information processing both verbally and non-verbally in communicating in online classes. Media wealth theory believes that using the right media will increase task performance [15].

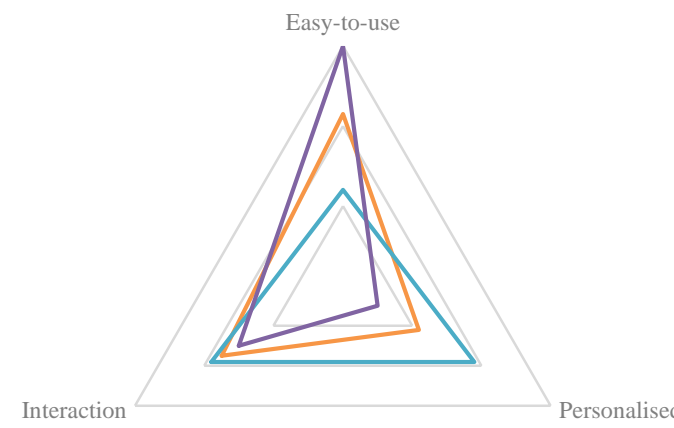

$\longrightarrow$ Zoom $\longrightarrow \mathrm{VU} \longrightarrow \mathrm{GC}$

Figure 6. The Correlation Between the Measured Variables and Student Acceptance

Either GM and Zoom are the same as a video conferencing tool. In fact, [16] stated that both platforms also have several similar features. From the ability to join meetings via cell phones or attend via personal computers, with web application services or Android and iOS systems. To maintain privacy, the two communication devices also can mute the microphone and turn off the camera. However, the organizers, or socalled hosts, are responsible for meeting or muting participants' microphones. Other similarities, both parties also have the option to record the meeting [17]. 
There are also some differences or feature offerings obtained from each application. Specifically Zoom, this medium has more advanced offers, among which is preventing several people from speaking at the same time. For example in a class meeting, there are many questions asked, then the host can use Zoom to provide opportunities for other participants [18]. Another advantage of Zoom is that Zoom can be obtained free of charge since it was first released. But this free Zoom course is only limited to 40 minutes. Besides, it is not permitted to record conversations or save meeting files. This feature can only be accessed by premium customers. But you can still accommodate up to 100 participants even with a free account [19]. On the contrary, according to [20] VU has advantages both in terms of system and its completeness. VU has been integrated with Unesa's academic services to support the learning needs of students. Despite this, several obstacles were revealed by users both students and lecturers. Some of them are unstable network connections that make contact lost both in terms of audio and visually.

In terms of appearance, Google Meet is a bit irregular. Somewhat odd compared to Google's habits that often design things with the simplest possible and not many trinkets [21]. But the advantages of Google Meet, everyone can appear at one time. The person who is speaking will be highlighted with the speaker symbol in his video. To share documents, GM is very easy. The screen that you display on Google Meet can be turned into a presentation screen to display the files that need to be displayed in all meetings. The file can then be sent via Google Drive. Currently, GM can be accessed free of charge by everyone who has a Google account. But until the end of September 2020, it will be limited to 60 minutes duration. This is certainly sufficient to simply conduct a brief coordination meeting [22].

This study gives VU platform special notes. More detailed research is needed to lead the lack of popularity of VU, even for academics at Unesa. Researchers assume that, due to many reasons, overall VU is not the students' first option. Firstly, VU is more focused on developing a service, but it is not followed up either directly or through lecturer intermediaries with dissemination to students. Second, the VU display is intuitive but is not supported by an adequate network of servers. Evidenced by the device frequency down as multiple users access it. Finally, the possibility that can occur is that students prefer the 'private' platform in person. Choosing the GM and Zoom systems, according to students, gives satisfaction and ease of accessing the network without having to use academic email to access them. Further research is required, however, because this study is restricted to certain subjects. For measuring the events occurring on the VU platform more detailed research methods with larger populations are required.

\section{CONCLUSION}

VU, Zoom, and GM platforms have almost the same features. The three platforms were able to support students to conduct lectures during the Covid-19 pandemic. Because the platform was created to facilitate the perpetrators of work from home, freelancers, or anyone who needs video communication with many people. This research is important to utilize various theories to investigate the suitability of the platform with each student's environment. These findings indicate that items that are supported in student admission contribute to the selection of the v-learning platform. The results of this study indicate that the use of different online platforms has an impact on a lecture on new forms of interaction. Certain tasks can't be treated as lectures in college following an improvement in learning outcomes. In future studies, certain weaknesses can need additional consideration. Next, the effects of regression must be precisely interpreted. Statistical analyzes, for example, an experimental design, are recommended for evaluating the relationship between faculty and student admissions. Furthermore, what needs to be considered in the next research is to provide opportunities for students to choose a v-learning platform independently according to voting. It also needs to be considered, involving several lecturers supporting the courses to participate in exploring information related to the acceptance of the platform that is applied during lectures. So that more detailed information can be known and felt its effectiveness in meeting learning objectives.

\section{ACKNOWLEDGMENT}

This study was never authorized without guidance and awareness from Universitas Negeri Surabaya, Faculty of Engineering, Department of Home Economics. The author would like to thank the students who participated in this research. Moreover, thank you for the support of the participating colleagues, to help improve the Department of Home Economics by obtaining useful results from the study for a better future.

\section{REFERENCES}

[1] [1] J. A. Pramukantoro, "perbedaan model pembelajaran kooperatif two stay two stray (TSTS) dengan group investigation (GI) terhadap hasil belajar siswa pada kompetensi menerapkan dasar-dasar teknik digital Viryan Gerry Pradhana"

[2] N. Asnawi, "Pengukuran Usability Aplikasi Google Classroom Sebagai E-learning Menggunakan USE Questionnaire ( Studi Kasus : 
Prodi Sistem Informasi UNIPMA )," vol. 1, no.

2, pp. 17-21, 2018.

[3] A. Shadat, M. Sayem, B. Taylor, and M. Mcclanachan, "Effective use of Zoom technology and instructional videos to improve engagement and success of distance students in Engineering," no. February 2018.

[4] K. T. Martono and O. D. Nurhayati, "implementation of android based mobile learning application as a flexible learning," vol. 11, no. 3, pp. 168-174, 2014.

[5] U. N. Surabaya and U. P. Indonesia, "applicationbased instructional tools for enhancing students ' problem-solving skills in home economics," vol. 9, no. 2, pp. 46-56, 2017.

[6] J. Bourne, D. Harris, and F. Mayadas, "online engineering education : learning anywhere, anytime *," vol. 9, no. 1, 2005.

[7] I. F. Romadhoni and L. Nurlaela, "Higher Order Thinking Skills to Enhance Millennial Students Through Active Learning Strategies," vol. 201, no. Aptekindo, pp. 91-94, 2018.

[8] Fitria Rahmawati, "E-Learning Implementation : Its Opportunities and Drawbacks Perceived by EFL Students," 2014.

[9] G. Salmon, B. Ross, E. Pechenkina, and A. Chase, "The space for social media in structured online learning," vol. 23, no. 1063519, pp. 1-14, 2015.

[10] I. Pembelajaran, D. Untuk, M. Mutu, P. Sebagai, D. Diterapkannya, and S. Distancing, "Albitar Septian Syarifudin Universitas Trunojoyo Madura , Jalan Raya Telang, Bangkalan,” pp. 31-34.

[11] L. Nurlaela, S. C. Wibawa, S. Handajani, M. Wahini, M. G. Miranti, and I. F. Romadhoni, "Preparing Competitive Graduates of Vocational School through Revitalization Program," vol. 335, no. ICESSHum, pp. 376-381, 2019.

[12] H. Huang, "Toward constructivism for adult learners in online learning environments," vol. 33 , no. $1,2002$.

[13] C. Dorai and A. Stewart, "ELM-N : E-Learning Media Navigator,” pp. 634-635, 2001.
[14] P. T. Pendidikan and U. Dan, "Pengaruh tingkat pendidikan, usia dan pengalaman kerja terhadap prestasi kerja karyawan,” 2007.

[15] L. Nurlaela, N. Astuti, I. F. Romadhoni, N. Purwidiani, and S. Handajani, "Students' Skills In Making Questions, Are They Indicators Of Their Thinking Skills?," in 2019 IEEE Eurasia Conference on IoT, Communication and Engineering (ECICE), Oct. 2019, pp. 100-104, doi: 10.1109/ECICE47484.2019.8942761.

[16] G. Basilaia, M. Dgebuadze, M. Kantaria, and G. Chokhonelidze, "Replacing the Classic Learning Form at Universities as an Immediate Response to the COVID-19 Virus Infection in Georgia," no. March, 2020, doi: 10.22214/ijraset.2020.3021.

[17] S. Bhat, R. Raju, A. Bikramjit, and R. D. Souza, "Leveraging E-Learning through Google Classroom : A Usability Study," no. January, 2018, doi: 10.16920/jeet/2018/v31i3/120781.

[18] R. A. S. Al-maroof and M. Al-emran, "Students Acceptance of Google Classroom : An Exploratory Study using PLS-SEM Approach,” pp. 112-123.

[19] I. F. Romadhoni, L. Nurlaela, and A. Sutiadiningsih, "Re-Create Systematized Interpersonal Skills Learning Models in Millennial Vocational Education and Training," vol. 406, no. Iconhomecs 2019, pp. 65-71, 2020.

[20] C. Pendidikan, "Niknik Mediyawati, Ninuk Lustyantie, and Emzir," vol. 38, no. 1, pp. 75-89, 2019, doi: 10.21831/cp.v38i1.22245.

[21] R. R. Burdorf A, Porru F, “The COVID-19 (Coronavirus) pandemic: consequences for occupational health," vol. 46, no. 3, pp. 229-230, 2020, doi: 10.5271/sjweh.3893.

[22] K. Ishii, M. M. Lyons, and S. A. Carr, "Revisiting media richness theory for today and future," Hum. Behav. Emerg. Technol., vol. 1, no. 2, pp. 124131, 2019, doi: 10.1002/hbe2.138. 